\title{
Nutritive stress and cytokinin status in Norway spruce seedlings (Picea abies L. Karst.)
}

\author{
Klaus v. SCHWARTZENBERG*, Heinz HAHN \\ Biozentrum Klein Flottbek und Botanischer Garten, University Hamburg, Ohnhorststr. 18, 22609 Hamburg, Germany
}

(Received 29 March 2004; accepted 14 March 2005)

\begin{abstract}
The content of cytokinins was analysed in shoots and roots from spruce seedlings (Picea abies L. Karst.) grown on various hydroculture media either with complete nutrient supply (control medium) or with deficiencies for some nutrients (stress medium). The cytokinins zeatin riboside and isopentenyladenosine were determined by an indirect competitive enzyme-linked immunosorbent assay (ELISA) in HPLC-purified extracts. The shoots of spruce seedlings grown on stress medium plus aluminum ions $\left(\mathrm{Al}^{3+}, 0.8 \mathrm{mM}\right)$ showed approximately 5 -fold higher concentration of zeatin riboside and isopentenyladenosine than the controls. When the auxin naphtylacetic acid ( $1 \mu \mathrm{M})$ was added to the stress medium, also higher levels of cytokinin ribosides were measured in the shoots. In the roots however, cytokinin riboside levels did not increase significantly, neither under $\mathrm{Al}^{3+}$ nor auxin treatment. The model experiments with spruce seedlings grown under controlled conditions support previous monitoring data on declining forest stands and show that nutritive stress can significantly increase the cytokinin content in the shoot of Norway spruce.
\end{abstract}

cytokinin / forest decline / nutrient deficiency / Norway spruce / Picea abies

Résumé - Stress nutritionnel et teneur en cytokinines chez des semis d'épicéa. Le contenu en cytokinines des parties aériennes et racinaires de jeunes semis d'épicéas (Picea abies) élevés en culture hydroponique sur différents milieux a été étudié. Il s'agissait soit de milieux comportant tous les éléments nutritifs (témoin), soit de milieux déficients en certains nutriments (stress). Le contenu en cytokinines (zéatine riboside et isopentényladénosine) a été déterminé à l'aide de la méthode d'inhibition compétitive (ELISA) sur des extraits purifiés par HPLC. Les pousses de semis élevés sur milieu «stressant » contenant des ions aluminium $\left(\mathrm{Al}^{3+}, 0,8 \mathrm{mM}\right)$ présentent une concentration en ces deux cytokinines environ cinq fois plus élevée que celle des plants témoins. Lorsque l'auxine, acide naphtylacétique (1 $\mu \mathrm{M})$, est ajoutée au milieu « stressant », on constate aussi des niveaux plus élevés de ces ribosides de cytokinines dans la partie aérienne. Par contre dans la partie racinaire, ces derniers n'augmentent pas significativement, que ce soit en présence d'Al ${ }^{3+}$ ou d'auxine. Cet essai sur semis en conditions contrôlées confirme des résultats précédents portant sur des peuplements d'épicéas dépérissant. Cela montre qu'un stress nutritif peut augmenter significativement le contenu en cytokinines des pousses d'épicéa commun.

cytokinine / dépérissement forestier / déficit nutritionnel / épicéa commun / Picea abies

Abbreviations: Equ.: equivalents, dw: dry weight, [9R]iP: isopentenyladenosine, NAA: naphtyl acetic acid, [9R]Z: zeatin riboside.

\section{INTRODUCTION}

Trees of Norway spruce suffering of symptoms of forest decline very often show early senescence, needle loss, changes in annual ring width or changes in root morphology $[1,10]$.

For plant hormones like cytokinins it has been demonstrated that they are involved in some of these developmental processes, e.g., root growth or senescence $[8,13]$. For model plants the importance of cytokinins for the development was corroborated by transgene overexpression studies using the cytokinin biosynthetic gene isopentenyltransferase (ipt) $[6,22]$ or the cytokinin degradation gene cytokinin oxidase $(c k x)[9,24]$. The ipt-overexpression leads to a strong increase of the endogenous cytokinin content resulting in plants with enhanced budding and a strongly reduced root growth. The $c k x$-overexpression leads to cytokinin deficiency and in consequence the activity of the vegetative and floral shoot apical meristems and leaf primordia was diminished. On the root level however, the activity of the meristem was enhanced leading to stronger root growth [24].

With respect to forest decline and tree damage it was discussed that the symptoms of environmentally stressed trees might be related to an altered status of plant hormones [4, 16, 17]. A correlation of tree damage and alterations in cytokinin

* Corresponding author: kvschwartzenberg@iangbot.uni-hamburg.de 
status was demonstrated for declining Norway spruce trees from forest stands, which showed significantly increased levels of the cytokinin ribosides isopentenyladenosine and zeatin riboside in needles $[19,21]$. These works have also shown that the level of cytokinin ribosides in the needles was correlated with the nutritional status of the spruce trees. In a forest stand affected by atmosphere derived acid deposition young declining spruce trees (approx. 15 years old) showing chlorosis and needle loss had a strongly elevated needle content of cytokinin ribosides when compared to neighbouring trees having received fertilisation and liming and showed consequently a low degree of needle loss and chlorosis. For Sitka spruce trees Collier and co-workers found that mature trees sprayed with different combinations of $\mathrm{N}$ had elevated cytokinin levels in their needles [5]. These authors concluded that the cytokinin content might be used as a sensitive bioindicator of $\mathrm{N}$ pollution in Sitka spruce. Also Kraigher and Hanke [15] have shown in field experiments, that the determination of cytokinin ribosides in Norway spruce seedlings has a potential for monitoring soil born stress.

It is obvious that under forest conditions it is difficult to assess the relationship between altered hormonal status and developmental changes or tree vitality because of the complexity of environmental factors. In this work we therefore used controlled conditions in order to address the question how the level of endogenous cytokinins might be affected in declining trees suffering from nutritive stress. We used Norway spruce seedlings growing on hydroculture media with different composition as an easy to handle system. In order to mimic the situation in a stressed forest stand we chose a synthetic medium composed according to the mineral analysis of a soil solution collected from a forest stand suffering from acidic deposition and nutrient shortage as published in [12]. In this work Junga proposes a hypothesis of disturbed hormonal balance for spruce under nutritive stress based on the observation that acidic conditions in combination with phytotoxic $\mathrm{Al}^{3+}$ ions damage the root primary meristems as a site of cytokinin biosynthesis. The consequently reduced cytokinin biosynthesis is thought to lead to a higher auxin/cytokinin ratio in the root, thus inducing the formation of secondary roots. The increased number of root meristems is then proposed to be responsible for an elevated export of cytokinins to the shoot, where cytokinin promoted effects could then cause an increased flux of auxin from the shoot to the root. As this hypothesis seems compatible with the finding of increased levels of cytokinins in needles of damaged spruce, we attempt to further analyse the question, whether a hormonal disequilibrium in the root of stressed trees can affect cytokinin levels in the shoot by administering either $\mathrm{AlCl}_{3}$ or the synthetic auxin naphtyl acetic acid. Results are discussed with respect to the suitability of spruce seedlings as a model system to investigate physiological consequences of soil acidification.

\section{MATERIAL AND METHODS}

\subsection{Hydroculture of spruce seedlings}

In order to check under laboratory conditions, whether nutritive stress has an impact on the cytokinin status, seeds of Norway spruce
Table I. Composition of basal media used for the growth of Norway spruce seedlings (according to Junga [12]). Basal media were used at different $\mathrm{pH}$ or with additives, see Table II.

\begin{tabular}{lcc}
\hline & $\begin{array}{c}\mathrm{CONTROL} \\
(\mathrm{mmol} / \mathrm{L})\end{array}$ & $\begin{array}{c}\text { STRESS } \\
(\mathrm{mmol} / \mathrm{L})\end{array}$ \\
\hline $\mathrm{NH}_{4} \mathrm{HSO}_{4}$ & - & 0.238 \\
$\mathrm{NaNO}_{3}$ & - & 0.099 \\
$\mathrm{KNO}_{3}$ & - & 0.123 \\
$\mathrm{NH}_{4} \mathrm{NO}_{3}$ & 1.77 & 0.0762 \\
$\mathrm{FeSO}_{4}$ & - & 0.0197 \\
$\mathrm{FeCl}_{3}$ & 0.018 & - \\
$\mathrm{KCl}$ & 0.95 & - \\
$\mathrm{MgSO}_{4}$ & 0.61 & 0.04 \\
$\mathrm{MnSO}_{4}$ & $0.3 \times 10^{-3}$ & 0.0236 \\
$\mathrm{CaCl}_{2}$ & 1 & 0.14 \\
$\mathrm{~K}_{2} \mathrm{HPO}_{4}$ & - & 0.0161 \\
$\mathrm{KH}_{2} \mathrm{PO}_{4}$ & 0.32 & - \\
$\mathrm{H}_{2} \mathrm{SO}_{4}$ & - & 0.12 \\
$\mathrm{H}_{3} \mathrm{BO}_{3}$ & $16 \times 10^{-3}$ & $13.9 \times 10^{-3}$ \\
$\mathrm{ZnSO}_{4}$ & $0.63 \times 10^{-3}$ & $9.96 \times 10^{-3}$ \\
$\mathrm{CuSO}_{4}$ & $0.32 \times 10^{-3}$ & $0.0160 \times 10^{-3}$ \\
$\mathrm{Na}_{2} \mathrm{MoO}_{4}$ & $0.033 \times 10^{-3}$ & $0.165 \times 10^{-3}$ \\
$\mathrm{KI}_{\mathrm{CoSO}_{4}}$ & - & $0.722 \times 10^{-3}$ \\
$\mathrm{NaCl}$ & - & $0.019 \times 10^{-3}$ \\
\hline & 0.205 & - \\
\hline
\end{tabular}

Picea abies L. Karst. (Staatsklenge Nagold, Herkunft 84008, Forstamt Enzklösterle) were spread out on sterile water agar (1\%) for germination at $20^{\circ} \mathrm{C}$. Three weeks after germination seedlings without visible microbial infection were selected and transferred to hydroculture according to Junga [12]. For hydroculture we used glass beakers $(2 \mathrm{~L}$, diameter $13 \mathrm{~cm}$ ), in which 35 seedlings were fixed with V2A-steel nets (wire diameter $0.56 \mathrm{~mm}$, mesh width $4 \mathrm{~mm}$ ). The net was fixed in $10 \mathrm{~cm}$ height above the bottom of the vessel, which was covered with the lid of a petridish (diameter $14 \mathrm{~cm}$ ). The vessels were autoclaved $\left(120{ }^{\circ} \mathrm{C}, 30 \mathrm{~min}\right)$ and their bottom part was darkened with black paper. Per culture vessel $1.5 \mathrm{~L}$ of sterile culture medium were used. Cultures with visible microbial infections were discarded. We considered the culture system as semi-sterile, no further sterility tests were carried out.

A CONTROL medium according to Ingestad was chosen as it is based on the mineral content determined in spruce plants and therefore provides an equilibrated nutrient supply, see [11, 12]. The basal STRESS medium, was composed according to the soil solution of a declining spruce forest stand (BLF-medium, [12]) and contained lower amounts of nutrients, especially calcium and magnesium (Tab. I). In one set of STRESS-cultures $\mathrm{AlCl}_{3}(0.8 \mathrm{mM})$ was added to the medium. For $\mathrm{Al}^{3+}$-ions it is known that they have phytotoxic effects on roots (e.g., [7, 14, 16]). In corresponding STRESS treatments without $\mathrm{Al}^{3+}$, the concentration of the $\mathrm{Cl}^{-}$counter ions was maintained equal to the $\mathrm{AlCl}_{3}$ treatment by supplementing the culture medium with $2.4 \mathrm{mM} \mathrm{NaCl}$.

In another set of STRESS-cultures the hormonal balance of the seedlings was altered by the addition of naphtyl acetic acid (NAA) as a synthetic auxin.

For the first 4 weeks all seedlings were cultivated on CONTROL medium at $\mathrm{pH} 5.8$ (Tab. I, according to [12]). In order to expose the plants to different nutrient supply, parts of the seedlings were transferred to STRESS media with a reduced nutrient content (Tab. I). 
Table II. Variations of culture media for hydroculture of spruce seedlings.

\begin{tabular}{cccccc}
\hline \multicolumn{2}{c}{ Complete nutrient supply } & \multicolumn{4}{c}{ Reduced nutrient supply } \\
\hline CONTROL pH 5.8 & CONTROL pH 3.8 & STRESS NaCl & STRESS NaCl & STRESS AlCl $l_{3}$ & STRESS NAA \\
& & $2.4 \mathrm{mM}, \mathrm{pH} 5.8$ & $2.4 \mathrm{mM}, \mathrm{pH} 3.8$ & $0.8 \mathrm{mM}, \mathrm{pH} \mathrm{3.8}$ & $\mathrm{pH} \mathrm{3.8,1 \mu M}$ \\
\hline
\end{tabular}

Seedlings grown on STRESS medium to which either $\mathrm{AlCl}_{3}, \mathrm{NaCl}$ (control for $\mathrm{AlCl}_{3}$ treatment) or the synthetic NAA was added, were compared to those grown on CONTROL medium as described in Table II. Seedlings were cultivated on the various media, which were replaced every 4 weeks. The cultures were placed at $20^{\circ} \mathrm{C}$ in constant light with ca. $90 \mu \mathrm{E} \mathrm{m}^{-2} \mathrm{~s}^{-1}$ (Osram LW58/77 Fluora).

After 20 weeks the seedlings were harvested and the roots were cut from the shoot. Samples were frozen in liquid nitrogen, freeze dried and homogenized to a fine powder using an electric coffee mill. Until cytokinin and chlorophyll extraction the samples were stored at $-20{ }^{\circ} \mathrm{C}$.

\subsection{Cytokinin extraction and determination}

Samples of shoots (needles and stem) or roots were extracted according to the method described in [20]. The powder of roots or shoots (ca. $100 \mathrm{mg}$ ) was extracted in methanol at $58{ }^{\circ} \mathrm{C}$ for $15 \mathrm{~min}$. Extraction was continued for another $30 \mathrm{~min}$ at $4{ }^{\circ} \mathrm{C}$. Cell debris was sedimented by centrifugation for $10 \mathrm{~min}$ at $500 \times \mathrm{g}$. The supernatant was adjusted to a methanol concentration of $80 \%$ by addition of distilled water and was then filtered through a glass fibre filter (Schleicher und Schüll, No. 6) and a cellulose acetate filter (pore width $0.45 \mu \mathrm{m}$, Sartorius Göttingen, Germany). The extract was passed through a SepPak C18 Cartridge (Millipore, Eschborn, Germany). The cytokinin containing effluent was evaporated to dryness by a rotary evaporator and taken up in $500 \mu \mathrm{L}$ of $35 \%$ methanol $(\mathrm{v} / \mathrm{v})$. The samples were submitted to preparative HPLC and the fractions containing zeatin riboside and isopentenyladenosine were collected [19]. Cytokinin ribosides were determined by an indirect competitive ELISA (enzymelinked immunosorbent assay) according to [19]. Per treatment (2 cultures) 4 extracts were prepared and separated by HPLC. For measuring cytokinins in the HPLC effluents 16 ELISA determinations per treatment were performed from which the mean values and standard deviation were calculated. Results were corrected for recovery losses by multiplication with 1.25 and are expressed as equivalents of zeatin riboside or isopentenyladenosine. The validation of the HPLC-ELISA based method for cytokinin determination in spruce (including antibody specificities, recovery rates and standard addition curves) was previously published $[19,20]$.

\subsection{Chlorophyll determination}

Chlorophyll was extracted from the shoot material with $85 \%$ aceton $(\mathrm{v} / \mathrm{v})$. After elimination of cell debris by centrifugation $(1000 \times g$, $120 \mathrm{~min}$ ) the content of chlorophyll $\mathrm{a}$ and $\mathrm{b}$ was determined according to the method described in [18].

\section{RESULTS AND DISCUSSION}

\subsection{Reactions of spruce seedlings to different nutrient supply}

We cultivated spruce seedlings in hydroculture using media with different nutrient composition as previously published by Junga [12] (Tabs. I, II).

The biomass production was lower for the seedlings grown on STRESS-pH 3.8 when compared to the CONTROLs
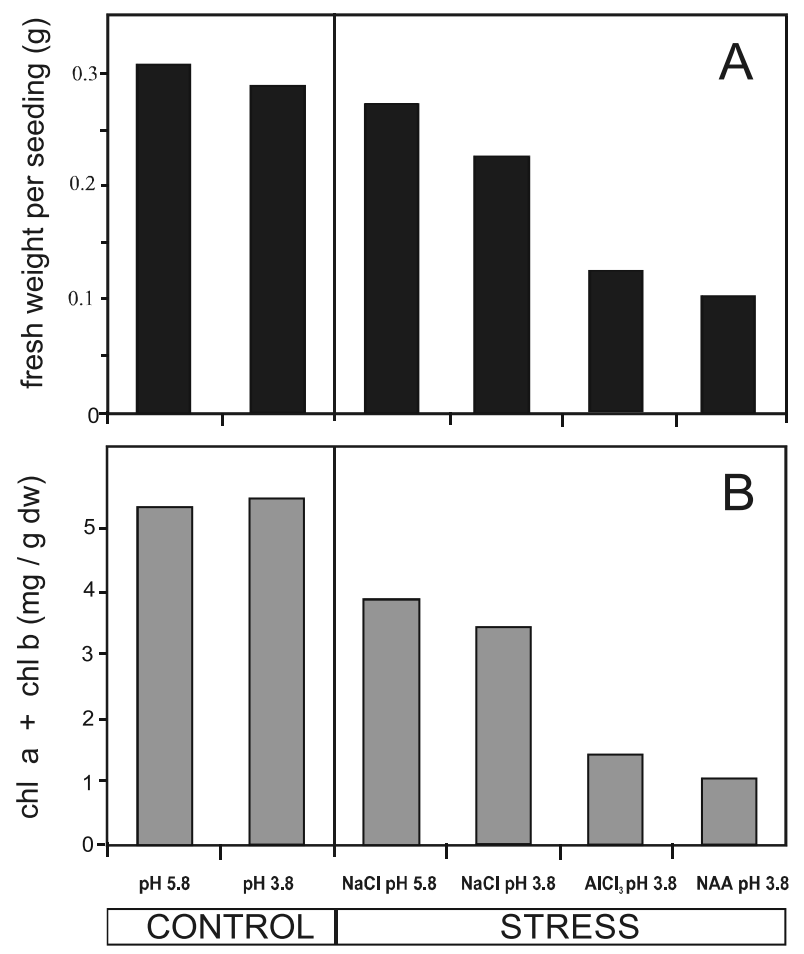

Figure 1. Fresh and dry weights (A) of 27 week old Norway spruce seedlings and chlorophyll content $(\mathbf{B})$ in shoots (needles and stem material) after growth on different hydroculture media (see Tab. I). Mean values from 35 plants.

(Fig. 1A). Although biomass production of STRESS-pH 5.8 grown seedlings was only slightly reduced, the chlorophyll measurements clearly showed a reduction of needle pigments for all cultures grown on STRESS media. For the STRESS$\mathrm{AlCl}_{3}$ and NAA variants the chlorophyll content was 4 and 5 -fold lower compared to the controls confirming the observation of a strong needle chlorosis of the seedlings (Fig. 1B, Tab. III).

Although no clear-cut effect could be seen with respect to the shoot/root ratio, a major difference between the CONTROL and the STRESS plants was found in the frequency of lateral roots (Tab. III). CONTROL plants showed only few lateral roots which mostly emerged close to the hypocotyl. Seedlings grown on STRESS media however, had an increased number of lateral roots, which inserted also in the apical region of the primary root. The strongest lateral root production was observed for the seedlings treated with the auxin NAA.

\subsection{Cytokinin ribosides in seedlings}

Cytokinin analysis was restricted to zeatin riboside and isopentenyladenosine as these compounds have been shown to accumulate in the needles of damaged trees [21]. 
Table III. Description of spruce seedlings grown for 27 weeks on different hydroculture media (see. Tab. II).

\begin{tabular}{|c|c|c|c|c|c|}
\hline & Needle chlorosis & Root colour & Number of lateral roots & Insertion of lateral roots & $\begin{array}{c}\text { Shoot/root ratio } \\
\text { (FW/FW) }\end{array}$ \\
\hline $\begin{array}{l}\text { CONTROL } \\
\text { pH } 5.8\end{array}$ & - & yellow/white & $(+)$ & basal & 4.9 \\
\hline $\begin{array}{l}\text { CONTROL } \\
\text { pH } 3.8\end{array}$ & - & yellow/white & + & basal & 5.7 \\
\hline $\begin{array}{l}\text { STRESS NaCl } \\
\text { pH } 5.8\end{array}$ & + & yellow/white & ++ & basal and apical & 3.6 \\
\hline $\begin{array}{l}\text { STRESS NaCl } \\
\text { pH } 3.8\end{array}$ & + & dark brown & +++ & mostly apical & 7.0 \\
\hline $\begin{array}{l}\text { STRESS } \mathrm{AlCl}_{3} \\
\mathrm{pH} 3.8\end{array}$ & ++ & dark brown & ++++ & mostly apical & 6.9 \\
\hline $\begin{array}{l}\text { STRESS NAA } \\
\text { pH } 3.8\end{array}$ & ++ & dark brown & ++++ & basal and apical & n.d. \\
\hline
\end{tabular}

n.d. not determined, - not visible, + very low, ++++ very high, (intermediate levels indicated by ++ to +++ ).

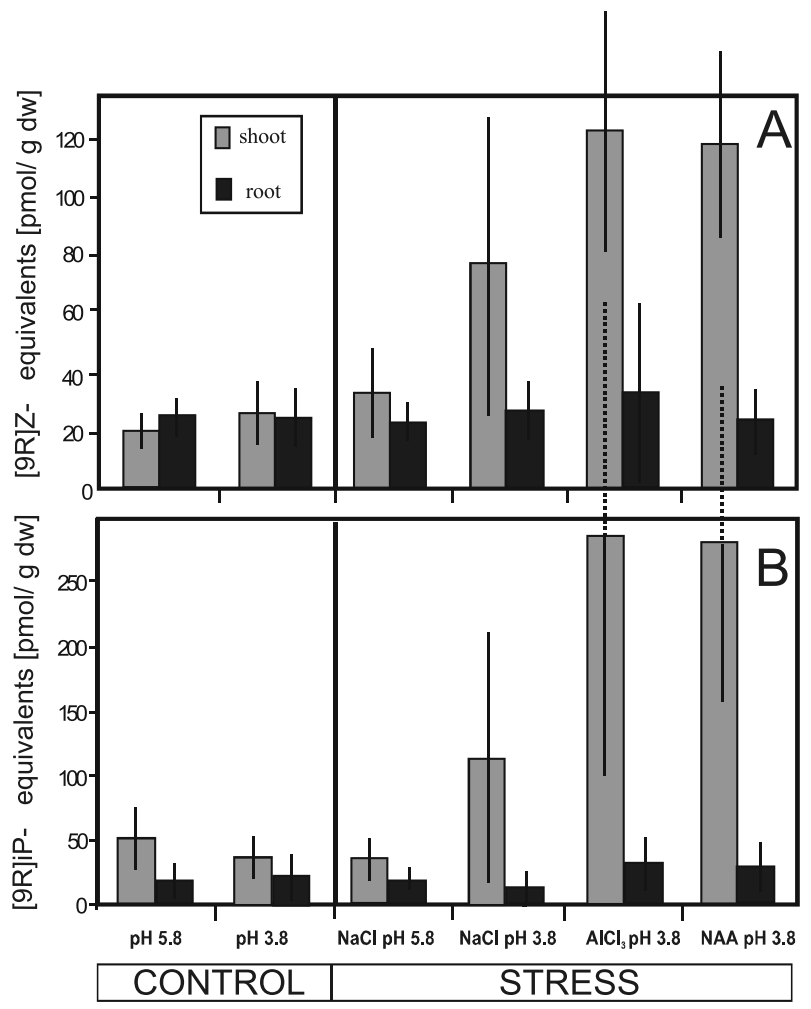

Figure 2. Content of (A) zeatin riboside ([9R]Z) and (B) isopentenyladenosine ([9R]iP) in shoots and roots of 27 week old Norway spruce seedlings. Cytokinin extractions were carried out in duplicate per culture. Per variant 2 hydrocultures were analysed. Results are mean values and standard deviations of 16 ELISA measurements per treatment (shown is one representative experiment out of 3 ).

From Figures $2 \mathrm{~A}$ and $2 \mathrm{~B}$ it is obvious that in almost all shoot samples the content of isopentenyladenosine is higher than the content of the zeatin riboside.

Comparing the content of cytokinin ribosides in the roots of the seedlings no significant differences could be measured for the different treatments.
However, the shoots of all STRESS-grown seedlings showed higher concentrations of zeatin riboside than the controls (Fig. 2A). In two assays with STRESS medium $\mathrm{NaCl}$ was added to the stress medium in order to serve as an additional control for the $\mathrm{AlC}_{3}$-treatment. At the administered $\mathrm{NaCl}$ concentration $(2.4 \mathrm{mM})$ we did not observe morphological effects when compared to STRESS medium without $\mathrm{NaCl}$ (not shown).

In the STRESS-pH 5.8 plants zeatin riboside tended to values only slightly above the corresponding CONTROL. Apparently nutrient shortage at $\mathrm{pH} 5.8$ did not strongly influence the cytokinin riboside content. But for the STRESS-plants at $\mathrm{pH} 3.8$ the average zeatin riboside level was 2.7-fold above the one of the CONTROL-pH 3.8 plants although the standard deviation was high. Besides analytical variations the high standard deviations between the ELISA measurements reflects also biological variations between the cultures and the use of clonal plant material would help to improve the precision in future experiments.

It can be concluded, that acidic $\mathrm{pH}$ of the nutrient solution alone is not responsible for the increase of zeatin riboside in the shoot as for the CONTROL-pH 3.8 and -pH 5.8 plants the contents were close to each other. The strongest increase was measured when $\mathrm{AlCl}_{3}$ or NAA were added to the STRESSmedium. The mean values for zeatin riboside were about 5 times higher than for the controls.

The data obtained for isopentenyladenosine showed to a great extent parallelism to the zeatin riboside data and thus confirmed the finding of highly elevated cytokinin riboside contents in the shoots of seedlings cultivated on $\mathrm{STRESS} \mathrm{AlCl}_{3}$ and STRESS NAA (Fig. 2B).

The synthetic reconstitution of the soil solution of an acidified spruce forest stand (STRESS) allows the assumption that under forest conditions nutrient shortage in combination with acidity and $\mathrm{Al}^{3+}$ ions might contribute to increased cytokinin riboside contents in spruce needles. The results of this work are in accordance with previous cytokinin measurements in declining spruce trees which also revealed higher levels of cytokinin ribosides in combination with lowered chlorophyll levels when compared to fertilized trees from the same forest stand [21]. 
Junga [12] had put forward the hypothesis, that stress in the rhizosphere could lead to a hormonal imbalance. The aim of the NAA treatment was to investigate, whether an artificial increase of auxin on the root level can induce changes of the cytokinin content in the shoot.

In discussing the elevated content of cytokinin ribosides in shoots of seedlings grown on STRESS-AlCl 3 - and STRESSNAA-medium, we assume that the increased number of lateral roots (Tab. II) contributes to a higher cytokinin production in the roots. For auxins it is well known that they induce lateral root formation [2] and in the STRESS-NAA plants the hormonal imbalance as generated by the addition of NAA leads to a largely increased number of lateral roots. Although in the roots themselves no significant increase of cytokinins was measured, it is hypothesised that the increased number of root apical meristems, which are sites of cytokinin biosynthesis [3], leads to an increased amount of cytokinin ribosides transported from the root to the shoot. The data obtained in the STRESS $\mathrm{AlCl}_{3}$ and STRESS-NAA-medium are in agreement with Junga's hypothesis of an altered hormonal balance under soil borne stress [12].

Schwartzenberg et al. [23] had shown that roots of seedlings grown on $\mathrm{STRESS}-\mathrm{AlCl}_{3}$ medium under hydroponic conditions showed a clear reduction in the rate of metabolisation of isopentenlyadenosine. We assume that the increased cytokinin levels in shoots of stressed seedlings could in addition to the increased number of root meristems result from metabolic fine tuning processes caused by the activity of enzymes involved in cytokinin degradation or -interconversion (like cytokinin oxidase, adenosine kinase or adenosine nucleosidase) which could be impaired in roots under the influence of the STRESS media.

We propose that spruce seedlings grown under different levels of nutritive stress could be used as an appropriate tree model system for molecular investigations on the regulation of the endogenous cytokinin content, a field on which substantial advances were made in the last years (see [8]).

Acknowledgements: The authors thank Dietmar Bettin, Heike Mazad and Dagmar König for experimental and technical support.

\section{REFERENCES}

[1] BMVEL - Bundesministerium f. Verbraucherschutz, Ernährung und Landwirtschaft (Ed.), Bericht über den Zustand des Waldes, Bonn, 2002

[2] Casimiro I., Beeckmann T., Graham N., Bhalerao R., Zhang H., Casero P., Sandberg G., Bennett M., Dissecting Arabidopsis lateral root development, Trends Plant Sci. 8 (2003) 165-171.

[3] Chen C.-M., Ertl J., Leisner S.M., Chang C.-C., Lokalisation of cytokinin biosynthetic sites in pea plants and carrot roots, Plant Physiol. 78 (1985) 510-513.

[4] Christmann A., Frenzel B., Untersuchungen zum Hormonhaushalt gesunder und kranker Nadelbäume, Allg. Forstzeitschrift, Heft $27 /$ 28/29 (1987) 746-749.

[5] Collier M.D., Sheppard L.J., Crossley A., Hanke D.E., Needle cytokinin content as sensitive bioindicator of $\mathrm{N}$ pollution in Sitka spruce, Plant Cell Environ. 26 (2003) 1929-1939.
[6] Faiss M., Zalubilova J., Strnad M., Schmülling T., Conditional transgenic expression of the ipt gene indicates a function of cytokinins in paracrine signaling in whole tobacco plants, Plant J. 12 (1997) 401-415.

[7] Godbold D.L., Fritz E., Hüttermann A., Aluminium toxicity and forest decline, Proc. Natl. Acad. Sci. USA 85 (1988) 3888-3892.

[8] Haberer G., Kieber J.J., Cytokinins. New insights into a classical phytohormone, Plant Physiol. 128 (2002) 354-362.

[9] Houba-Herin N., Pethe C., d'Alayer J., Laloue M., Cytokinin oxidase from Zea mays: Purification, cDNA cloning and expression in moss protoplasts, Plant J. 17 (1999) 615-626.

[10] ICP - International Co-operative Programme on Assessment and Monitoring of Air Pollution Effects on Forests (2003) http:// www.icp-forests.org.

[11] Ingestad T., Mineral nutrient requirements of Pinus silvestris and Picea abies seedlings, Physiol. Plant. 45 (1979) 373-380.

[12] Junga U., Sterilkultur als Modellsystem zur Untersuchung des Mechanismus der Aluminiumtoxizität bei Fichtenkeimlingen. Berichte des Forschungszentrums Waldökosysteme/Waldsterben, Universität Göttingen, 1984.

[13] Kende H., The cytokinins, Int. Rev. Cytol. 31 (1971) 301-338.

[14] Kinraide T.B., Toxicity factors in acidic forest soils: attempts to evaluate separately the toxic effects of excessive $\mathrm{Al}^{3+}$ and $\mathrm{H}^{+}$and insufficient $\mathrm{Ca}^{2+}$ and $\mathrm{Mg}^{2+}$ upon root elongation, Eur. J. Soil Sci. 54 (2003) 323-333.

[15] Kraigher H., Hanke D., Cytokinins in Norway spruce seedlings as tester organisms of forest soil pollution, in: Kraigher H., Batic F., Hanke D.E., Agerer R., Grill D. (Eds.), Proc. International Colloquium on Bioindication of Forest Site Pollution: Development of Methodology and Training (BIOFOSP), August 22-31, 1995, Ljubljana, pp. 95-100.

[16] Kremer H., Pfanz H., Hartung W., Die Wirkung saurer Luftschadstoffe auf Verteilung und Transport pflanzlicher Wachstumsregulatoren in Laub- und Nadelblättern, Allg. Forstzeitschrift, Heft 27/28/ 29 (1987) 741-744.

[17] Meyer F.H., Das Wurzelsystem geschädigter Waldbestände, Allg. Forstzeitschrift, Heft 27/28/29 (1987) 754-757.

[18] Röbbelen G., Untersuchungen an strahleninduzierten Blattfarbmutanten von Arabidopsis thaliana (L.) Heynh., Zeitschrift für induktive Abstammungs- und Vererbungslehre 88 (1957) 189-252.

[19] Schwartzenberg v. K., Lutze K., Hahn H., Determination of cytokinin content in needles of spruce (Picea abies (L.) Karst.) by an indirect enzyme linked immunosorbent assay, J. Plant Physiol. 133 (1988) 529-534.

[20] Schwartzenberg v. K., Der Cytokiningehalt in Nadeln unterschiedlich stark von Neuartigen Waldschäden betroffener Fichten (Picea abies (L.) Karst.), bestimmt mittels einer immunoenzymatischen Methode - ELISA, Dissertation Universität Bonn, 1989.

[21] Schwartzenberg v. K., Hahn, H., The cytokinin content in needles of Norway Spruce (Picea abies (L.) Karst.) with different degrees of damage, J. Plant Physiol. 139 (1991) 218-223.

[22] Schwartzenberg v. K., Doumas P., Jouanin L., Pilate G., Enhancement of the endogenous cytokinin content in poplar by transformation with the T-DNA gene ipt, Tree Physiol. 14 (1994) 27-35.

[23] Schwartzenberg v. K., Doumas P., Bonnet-Masimbert M., The metabolism of isopentenyladenosine in the roots of Norway spruce seedlings exposed to nutritive stress, Ann. Sci. For. 52 (1995) 57-65.

[24] Werner T., Motyka V., Laucou V., Smets R., Onckelen H.V., Schmülling T., Cytokinin-deficient transgenic Arabidopsis plant show multiple developmental alterations indicating opposite functions of cytokinins in the regulation of shoot and root meristem activity, Plant Cell 15 (2003) 2532-2550. 